\title{
The Resistance of Social Groups: Religious Behavior Phenomena during Covid-19 Pandemic
}

\author{
Adison Adrianus Sihombing ${ }^{1}$, Muassomah Muassomah ${ }^{2}$ \\ \{sonadi2017@gmail.com ${ }^{1}$, muassomah@bsa.uin-malang.ac.id ${ }^{2}$ \} \\ Puslitbang LKKMO Kementerian Agama Jkt ${ }^{1}$, Universitas Islam Negeri Maulana Malik Ibrahim \\ Malang ${ }^{2}$
}

\begin{abstract}
Religious groups are supposed to obey the rules of religion and government, yet they, in fact, showed a lot of resistance during the pandemic of Covid-19. Their resistance against the policy of social-physical distancing and health protocol is found in many regions. The current study aims to reveal and show the resistance behavior of religious groups covering the forms of the resistance and the influencing factors. It employs a qualitative descriptive approach through observations, interviews, and documentation on the online news. It concludes that religious groups have a strong social power with great compactness influenced by their figure. Each of them is subject and obedient to every single words of the figures. In short, the resistance happens due to the loss of religious figures who obey the government rules. In addition, it was found that scriptural literacy is very necessary so that religious adherents are willing and able to dialogue their faith with other disciplines and not fall into excessive subjectivism so that it seems that the practice of living religion becomes irrational and ignores "other" as happened during the PSBB/lockdown period.
\end{abstract}

Keywords: Resistance, religious groups, social behavior, pandemic, covid-19

\section{Introduction}

The phenomena of religious life in the global world during the pandemic of Covid-19 were counter-productive against the essence of religion which ideally brings peace and safety. There had been various attitudes and behavior of religious resistance against the policy of the government to enforce the lockdown and large-scale social restrictions (PSBB) in March May 2020. PSBB was issued to disconnect and prevent the transmission of Covid-19 which had become a global pandemic. Jamaah Tabligh still conducted an international gathering in Gowa, South Sulawesi attended by thousands of people [1]. A Religious event of Catholic, ordination of bishops was still held in Ruteng, Nusa Tenggara Timur Province [2]. Pastors kept forcing their congregations to attend a meeting for worship to prove that they were believers [3]. A pastor in Life Tabernacle Church along with the congregation of Pentecostal Oneness in Baton Rouge, United State, still conducted activities of worship with thousands of people [4]. Shincheonji Church in South Korea became the main source of infection of Covid19 because the congregation refused the treatment and preventive actions against the virus infection. About $60 \%$ of the total national infections is considered to be derived from the church [5], [6]. The above phenomena reflected resistance of religious groups against government policy. 
The religious phenomena confirmed that within emergency condition, when science failed to prove certainty and healing, people will easily accept the interpretation, rationalization, and justification of religious leaders [7]. It confirms the position of religion as the foundation of human life, especially during the hard times. Religion can provide meaning and promote human survival [8]. In common sense, people agree that religion can substantially contribute to promote health education and preventive actions against Covid-19 [9]. However, social reality proves that religious groups perform the hardest resistence against the policies related to Covid-19. They intentionally conduct activities involving hundreds even thousands of participants. Besides, they also open places of worship in which crowd gather.

Meanwhile, the study of religion in the pandemic of Covid-19 tends to examine the contestation of authority between religion and science in the modern world [10]-[13]. Scholars agree to support the idea of building relationships that strengthen one another, making dialogues and cooperation to cope with the complexity of life issues to develop human civilization. Another study assesses the religions that has been mediated in social media, which means that religion switches from empirical reality into virtual reality [14]. Religious learning is no longer performed through religious figures or experts but social media. The phenomena of religious behavior which are counter productive and various emerging views during the pandemic of Covid-19 are beyond scholar attention.

The reason the author uses a phenomenological approach to religion is because this study only intends to find the meaning of the phenomenon of religious behavior that emerged in the early days of COVID-19. In addition, this approach has also proven to be able to provide correct answers to religious problems. So that scholars usually use this approach in exposing religious issues, such as Eduardo Gross [15], Sonny [16], Zuzana Marie [17], Heddy [18], Ludger [19], Nurma [20], Peter McKenzie [21].

The study complements the shortcomings of the existing literature by providing a critical analysis on religious phenomena under the perspective of phenomenology. The religious phenomena show that religious leaders can influence people's practices, behaviors, and beliefs through the religious-based teachings. In this context, three questions are on concerns: firstly, the phenomena of religious behaviors happening during the pandemic; secondly, the factors influencing the phenomena; thirdly, the mission of the religion behind the resistance made during the pandemic. The answer to the third question is the main point of the current article.

This study is a descriptive qualitative research developed using phenomenology intended primarily to describe the religious symptoms under the perspective of the research subjects. The main attention is directed at awareness and knowledge of the subjects related to the religious behavior and actions. It refers to the religious behavior happening during PSBB or lockdown. Data are derived from information, articles, online news on the Internet related to religious practices during the pandemic, especially in March until June 2020. Phenomenology as a methodology aims to find the authentic meaning and ideal relationships behind the phenomena of relation in society.

This paper is based on three arguments: the fact that the global pandemic proves the immaturity of the congregation upon appreciating religion; the need of courage to conduct a dialogue across disciplines without losing the authenticity of their-own-religious truth; and the demand of the global pandemic to manuscript literacy so that the expected religious behavior responding positively to the life issues comes up. 


\section{Phenomenology}

The term "phenomenology" derives from the Greek word phenomenon (what appears) and $\log o s$ (science). Phenomenology means the science of phenomena or anything coming up in consciousness. Phenomenology is a philosophical approach that focuses on the analysis of the symptoms that come to human consciousness [22]. Mind perceives the variety of phenomena or experiences of human life hides meaning, so meaning must be found through awareness (Riyanto, 2018). Consciousness is the foundation and starting point to move, search, and find the meaning. For Husserl, consciousness has never been empty, but it is always connected with "the other", which he means by intentionality. Consciousness is always directed at the field of everyday life, which is intersubjective. Thus, human beings in the world are interconnected so that the consciousness formulated among them possesses social character that they share to one another. The togetherness process may occur because humans always assume that the symptom, either a thing or an event, they experience can also be undergone by others. It means an intersubjectivity of the world [18].

Phenomenology aims to describe the phenomena or symptoms of consciousness and to show how it is constructed [18]. It means that things can be seen from an object, from the way they present themselves that we can capture the picture of the object in consciousness [17]. Gross suggests that phenomenology fit with the activities of religious study. Religion as a phenomenon is rooted from human experience over their relationships with the holy, sacred, or transcendent reality [15]. This relationship manifests in different forms of expression, such as language, doctrinal formulations, stories and myths, rituals, hierarchies of religion and administrative structures, forms of popular religions, arts, musics, architectures, and so on [23]. The experience and religious behavior are explored, reflected in the perspective of phenomenology of religion to find meaning [24].

\section{Manuscript/scripture literacy}

Literacy is the ability to use spoken and written language to express thoughts and feelings in everyday life so that other people can understand well [25]. Literacy refers to a competence in reading and writing in a written or spoken language. In the context of religion, it is known as literalism. Literalism becomes a challenge to understand holy texts. It is an understanding on religious texts by reading them based on the literal meaning without any concern on the context (Hardiman, 2015). Literalism needs to be addressed with scripture literacy so that the reader is not stuck in the extreme understanding upon reading a text. Scripture literacy means the ability to interpret a text through contextual, cultural, social, and political consideration. Also, it considers the time that separates the reader and the author, so the meaning of the text can be correctly revealed. That is why hermeneutics is an inevitability (Hardiman, 2015).

\section{Relationality}

The terminology of relationality becomes a keyword in the philosophical thought of Fleet. As a philosopher of phenomenology, his attention focuses on the case of the existential experience of human beings. The implication is that the philosophy of relationality by Armadian has existential-phenomenological character. The fundamental thought as a phenomenological truth is that no part of human's everyday life is meaningless. The everyday- 
life experience of humans is a pilgrimage of subjectivity and relasionality with lyan. It means that human beings do not stop at being human, yet they are "subjective" and "relational" until they meet their Creator (Riyanto, 2018). Relationality is human nature. Nature means an inherent character within the subject. Thus, relationality is a characteristic which is inherent by nature within the subject (personal) since he/she is born. Relationality according to the perspective of Armadian is a transcendent activity of the subject. An activity where the subject crossed himself out of the closure and limitations towards others outside him/herself. Thus, relationality is an activity of directionality and openness. It means a motion of going out of ourselves towards others outside of me and openness to the other motions towards myself. The other, outside of "me" can be a "relation of me and text, me and phenomenon" (Riyanto, 2018).

According to Armada Riyanto, the relation of the subject with the text and also the subject with the phenomenon is dialogical. Dialogical means that the subject or the text and the phenomenon are both active. The subject moves out of himself towards the text and phenomenon. Text and phenomenon also move out towards the subject for "self consciousness". It allows the subject to have "phenomenological imagination", which is the ability to enter the world of the text that the reader seems to be the actors involved in the text or phenomenon. Phenomenological imagination delivers spirit and power to a text and phenomenon, so that the text and phenomenon which are previously dead and passive are alive and active (Riyanto, 2018).

\section{Mediatization of religion}

The development of information technology has changed the conventional communication patterns to the modern one, online. Internet-based modern communication is fast, broad, open, and able to penetrate the boundaries of space and time (Froust, 2011). On the one hand, internet-based modern communication brings positive changes to the religious life. Digital Media can enrich the source that presents religion in various dimensions [26]. However, internet is also considered as a threat against the social norms of religion and the authority of religious leaders [27]. It may happen because media can be a way of the existance of people's authority in the production of religious knowledge. It means that public participation in the production of religious knowledge increases. As a result, a source of authoritative knowledge is not single, no longer dependent on the charisma of religious leaders, but it refers to the channel of communication in different and more convergent forms. This shift is characterized by the technologization of religion [28]. Religious preaching is done through technology, displayed in social media, and widely spread fast [26].

The charisma of the leader used to be the deciding factor in the inheritance of values, the center of orientation, adored, and worshiped. Media distance the follower of a religion from leader and simultaneously turn compliance into a lawsuit because media have brought religion closer to the public by opening a broad space for public engagement. Public discussion through the community of netizens in Facebook, Tweeter, and Instagram shows that religion can be openly debated, even for issues which are not discussed previously in public [28]. Media technology bring a distance closer and bring human, message, discourse, and meaning together, that create a communication environment [29]. Media have provided the overall needs and satisfied all desire. Religion becomes the object of day-to-day discussion through the process of diverse and contestative interpretation. Religion is no longer absolute and elitist. Religion is represented in the popular form to reach out to the broad public [28]. 


\section{The resistance phenomena of religious groups}

The news related to religious group behavior during PSBB in Indonesia and lockdown in other countries are widely spread in the social or online media. There are various behaviors and views of people about the pandemic of Covid-19. As an example, a pandemic is perceived as a punishment and "calculation" to abortion and gay marriage [30]. The leader of Hindu (vegetarian) explained that the virus was Avatara, granted to restore the universal balance which was getting worse due to the increasing number of meat-eaters. Some teachers of India expressed that the virus was a collective negative karma and urged to return to a holistic and Sattvic lifestyle [7]. A priest in the US, in his speech, said that the pandemic was an extreme test of loyalty brought by the spirit of anti-Christ [4]. In Virginia, a priest kept opening his church and preaches "...unless I'm in jail or the hospital because people are healed" (in his church). In the end, he passed away due to Covid-19 [31]. Another case, a priest in the church of Tampa Bay, Florida asked all of his followers to shake hands with one another, while those who did not fulfill it were called 'sissy'. Church was seen as the safest place. He said with humor, "If you cannot be saved in church, you are in serious trouble" [32].

A group of muslims avoid the recommended preventive action by refering to Quran; "Allah is sufficient to us; and he is the extraordinary guardian" (The Noble Quran, 2016b) [9]. Similarly, in India, in the name of the sacred and hereditary tradition, Hindu-nationalists, the supporters of the political parties of Prime Minister, Narendra Modi rollicking, perform a ritual of drinking the urine of a cow to prevent Covid-19. A cow is believed to be the holy creatures that can prevent or heal a disease. One of the 200 drinkers said, "We have been drinking cow urine for 21 years, we also take a bath in cow dung. We have never felt the need to consume English medicine". [33], [34]. Drinking the urine of a cow and having a party are perceived to be potential treatments against Covid-19 [35]. The urine of a cow is believed to have a substance that can strengthen immunity and eradicate virus [36].

Christians also believe that consuming water together with sacred soil on the grave of a monk, Maronite Mar Charbel, in Mount Lebanon can be used as a medicine against the infection of Covid-19 [37]. Thousands of congregations in Shincheonji Church Yesus in South Korea still do worship resulted in many them are exposed to the virus of Covid-19. They believe that disease is a sin. The sufferer should attend the prayer to repent for sins [3], [38] [40].

Some Christians claim that Covid-19 is a proof that the plagues of the book of Revelation, and specifically, the seven seals of Revelation $6: 1-8: 1$, are happening now, and the return of Jesus is coming soon. For them, revelation can predict the pandemic of Covid-19 [40]. However, the more moderate leaders reject the idea that the pandemic is a punishment for sin. There has long been a tradition in the monotheistic religion that considers a disease a sin. Recently, radical Protestant fundamentalists and Catholics have been using the internet to spread their view that the pandemic is a punishment for various sins, from gay marriage, abortion, blasphemy, environmental pollution, paganism to magic [40].

Three meetings of Jamaah Tabligh in Malaysia, Pakistan, and India became the hotspot of Covid-19 [41], [42]. The members are stated positive Covid-19 [43]. The rate of Covid-19 infection among the ultra-orthodox Jews of Israel are very high compared to the other Israelis because they still carry the religious group prayers [44]. In the state of Punjab, Northwestern India, a 70-year-old Sikh, after returning from Italy and Germany, refused to be quarantined. He went to attend some religious meetings and even visited the festival of the Sikhs in another city. People in contact with him were tested and proved positive corona [45]. 
Another group that has not taken preventive actions is Jewish Haredi in Israel. Haredim is a group in Judaism Orthodox who strictly holds on to their interpretation of the law and Jewish values and against the modern values and practices. They believe that if they pray and learn, they can defeat the virus [46]. Another example 16.000 Muslim pilgrims visited Malaysia together, and after returning home, they spread COVID-19 to a half dozen countries [47].

Some muslims also interpret that Covid-19 as "soldiers of Allah/Corona virus is the army of God". The army of God means viruses which attack China who hurt the muslims in Uighurs [48]-[50]. Some also argue that COVID-19 is a test and warning from God that human beings are not arrogant [51]. In Aceh, Covid-19 is viewed as a continuation of the plagues coming in their ancestor's era, so when dealing with the plague,[52] they use the logic delivered by the cultural experts of Aceh by looking back at the practices in the past. There is a belief that the virus can be prevented when the finger is intermittently affixed to the leaves of henna [53]. The behavior of anti-science, carrying religious teachings, was agreed upon by the scholars in Aceh, so during the month of Ramadan 2020, no mosques were closed[54] even though Indonesian Ulema Council (MUI) and the Ministry of Religious affairs has issued a directive that places of worship should be free from the crowd [55]-[57].

News in the beginning of March 2020 stated that about 60 percent of the people infected Covid-19 in South Korea were from the cluster members of the church. Because, during the pandemic, they still perform ritual activity, indifferent to the warning of social/physical distancing clandestinely with high mobility of the sect members [58]. Another case occured in the international meeting of Jamaah Tabligh at Sri Petaling mosque, Malaysia (28 February - 1 March 2020). The event was attended by approximately 16,000 people, including 1,500 foreigners. This event became the largest source of the spread of Covid-19 in Southeast Asia. After the case in Malaysia, Jamaah Tabligh still conducted another event in Gowa, South Sulawesi (19-22 March 2020) during the fast-growing epidemic of Covid-19. Within the dangerous condition, this event was attended by 8.223 people. They had gathered, given hugs, and eaten together in one tray with three fingers. One of the committees, Mustari Bahranuddin, proudly claimed the resistance and said, "we are more afraid of God" rather than Covid-19 [1], [59], [60].

In addition, in the conditions where an assembly and a less-than-one-meter distance were prohibited, a religious event of Catholics was still held on March 19, 2020. Mass Ordination in East Nusa Tenggara was still held under the pretext of the participant reduction, from seven thousand to a thousand people, and facilitated with thermo gun, hand sanitizer, and tight supervision. Under those reasons, they still held the event solemnly, attended by public. They had a different opinion from that of provincial government by holding the rituals. The regent of Manggarai Flores, Deno Kamelus, was powerless against the resistance of Diocese of Ruteng Mgr Siprianus Hormat [2], [61]. Another case happened in the ritual of Nyepi for Hindu on March, 242020 at Prambanan Temple, Klaten which was still scheduled with limited number of participants, approximately two hundred people. The executive committee of the Center of Parisada Hindu Indonesia (PHDI) of Central Java expressed that the ritual of Nyepi will still be conducted. The governor of Central Java, Ganjar Pranowo along with Forum for Religious Harmony (FKUB) agreed to implement social distancing in the places of worship and public areas. In the city of Raipur, Bangladesh (March 18, 2020) thousands of muslims pray together to liberate Bangladesh from Covid-19. Under the Islamic faith, they run this event without the permission of the government and police. They show the prayer they call "the Six Quranic Verses of Healing” [62], [63]. 


\section{The factors of resistance}

Various attitudes, behaviors, actions and deeds that happen as religious phenomena articulate that religious people have different views with one another. According to the perspective of phenomenology, the variety of views and behaviors towards the global pandemic is driven from subjective experience that describes how humans build relationships with their religion. The resistant religious groups come up because in addition to distrusting science, Covid-19 leads to a significant change of the whole dimension of human life including the ritual practices. Making a major change to something that has long been consistently practised is something very hard and almost impossible for most people.

For Jews, praying at the wailing wall in Jerusalem is a very crucial tradition for them. Although Israel's chief of Rabbi, David Lau and Yitzhak Yosef, instructed the obedient Jews to stop visiting sacred sites, people still continue to pray there [40]. 2020 was a year when Jews celebrated the Easter day without any guests and a mosque in Regents Park. London was closed, and muslims were required to pray at home. Muslims have been instructed to postpone the booking of hajj and umrah [64]. Similar action was taken by Jamaah Tabligh, the largest missionary movement of Islam in the world reemphasize to get back to a way of life in the era of the Prophet Muhammad, praying and eating together in the mosque. Human beings should only fear of God. Disease and health come from Him. Only God can determine the death and life [11], [65].

Such belief stimulates the actions irrelevant to science. Religious people quickly and confidently conclude that the pandemic is a punishment because modern people has been disobedient with religion. As a result, the advice on at-home temporary worship is considered as an effort to keep the people apart from the houses of worship (God). On the other hand, some people take advantage on the advances in information technology as media of provocation. Anyone, whether he or she has sufficient knowledge of theology, can write and spread ideas, opinions, personal views about religion during the pandemic. As a result, people who general study religion from social media and Youtube may easily be influenced, being careless about the health protocol [54], [66].

Some religious practices have changed. All religious interactions in public spaces have been stopped, including rituals of prayers, offline religious services, religious schools, pilgrimage, and any religious celebrations. As an alternative, churches, mosques, and synagogues provided creative ways by providing online services through live streaming, radios, and televisions. It does not have a communal dimension of direct interaction, and Christians do not give the opportunity to take a part in the Eucharist. The obligation to comply with the habit of abstinence from eating meat on Fridays during Lent was suspended by some bishops of the Roman Catholic during the pandemic of Covid-19, which coincided with Lent in 2020 [67].

\section{The mission behind the resistance behavior of religious groups}

In a severely difficult situation, human beings are always looking for protection to the power believed to grant help. Religious people generally refer to God. Human beings perceive that building a relationship with God is an existential necessity. And, it will be more noticeably viscous when disaster struck. People get closer to God because religion is the framework that gives meaning and meaning [68], especially in times of stress (Frei-Landau et al, 2020; Crystal L. Park, Donald Edmondson 2013). It is considered as a resource that 
promotes resilience of the humans[8] and guides them in times of crisis [69]. Prayer becomes one of the common strategies and ways performed to face the difficulty.

Most people perceive that the attitude of resistance, ignorance, and other religious views on Covid-19 is something strange, illogical. Religious leaders, who are expected to play an important role in educating the society to be more anticipatory against the threat of the pandemic of Covid-19, provide ungrounded, illogical, and unscientific views about Corona virus. A relationship with God manifested in the worship leads to criticism and threatens a lot of people's safety. The nature of religion as a place to find peace, the depth of life, and hope is accidentally hidden and counter-productive [22]. Human's safety (life) becomes less valuable because of the inability to appreciate religion wisely. Giving a wise appreciation requires a deep and true understanding on the doctrine and the substance of the religion. In this context, scripture literacy is highly prominent. Scripture literacy means the ability of the followers to interpret the "text", so the content can be wisely and correctly understood.

Scripture literacy is necessary as a foundation to understand a text (religious teachings) upon looking for the original meaning as well as the dynamics of its development. The authentic meaning from the author is not only an "original message" but also a true reference. Because the meaning is a true reference, it has a "revisionist" or "corrective" intention in the sense of fixing the less precise meaning that has been widely spread (Riyanto, 2018). One important thing that becomes the nature or a kind of the sacred text it was written to build a civilization and life governance of human beings. It is impossible that a text is written to a ruin the civilization. A tyranny on a particular text may occur if people are too easy to deduce the meaning without any concern on the authentic purpose of the author, the context of the the author's era, and today's context. Therefore, hermeneutics is a necessity as the foundation so that the congregation are familiar with scripture literacy. This is a process of becoming, a process continually struggled, cultivated, and internalized in everyday life.

Another meaning that can be taken into account from religious behavior which is ignorant with science has indicated the darkness or loss of humanity orientation upon appreciating religious life. Religion is often reduced in to vertical relationship to God only. At this point, the humanity side of a religion is often overlooked. It is caused by the absence of human awareness. Awareness on the nature of human "relationality" with the "lyan", phenomenon, and "text". In the perspective of phenomenology, human always interpret everything in life because human world is meaningful. Phenomenology offers a broad tradition to study various ways of religious experience [19].

According to phenomenological perspective of Armadian, a religious experience is not seen as a single phenomenon in the sense of being independent. Phenomenon has a narrative, contrast, interpretive, and sustainable character. Phenomenon is narrative, which means that the experienced reality flows, not stagnant, dynamic, and it has a story. A story about the reality of human's everyday life, and he or she is the actor. The narrative appears when he or she is always looking for the meaning behind the reality. The reality is narrative because the nature of the event or phenomenon is relational. Events are narratives because they are related one another. Thus, the phenomenon relationality composes a story or narrative.

Phenomenon as a narrative often contrasts and feels strange. The actions of religious people who are ignorant with science are seen contrast and counter-productive, what is perceived to be right turns out completely different in reality. However, the contrast of the narrative makes the events of human life interesting. Human then asked, "what is the meaning of the contrast events?" That question triggered the elaboration of interpretation. The phenomenon/reality invites everyone to interpret because the nature of the reality is 
interpretive. Reality always invites a human around to make interpretation, so people find the meaning. Looking for the meaning of the phenomenon means getting into the event or immersing self within the reality. The subject "I" related to the phenomenon is "invited" to make interpretation (Riyanto, 2018).

Phenomenon is narrative and continuous, which means that the events are not separated. The events of life are continuous. Various events of human life will never happen without meaning. A mind does not perceive it only as a sole event, but it declares a meaning. Meaning necessitates methodology, so the hidden meaning behind the phenomenon can be revealed. Meaning is the hidden truths within phenomenon while phenomenon is a reality known for what it is. It means that the experience of human life is understood through typical approach which belongs to the subject. The world of human experience is a subjective world undergone, drawn, cultivated, and nourished from everyday life. From everyday life, human beings produce life values. The values become principles, the guidelines of their life. Thus, human life becomes meaningful and worth living.

\section{Conclusion}

The philosophical discourse about the phenomena of religious behavior during the global pandemic proved the significant role of religion for human life. Even though the era has been advanced and sophisticated, the position of religion remains irreplaceable as the existential need of human. The variety and plurality of interpretation in religions come up from the internalized views, knowledge, understanding, and values. It confirms the viscous subjective element upon religion because the understanding and interpretation of religion are always attached with the element of subjectivity. In this context, scripture literacy is necessary that the adherents of religions are willing and able to discuss about faith with the other disciplines. Besides, they are expected not to fall into an excessive subjectivism, so the practices of religious appreciation do not feel irrational and ignorant to the others as what happened during PSBB/lockdown.

The discourse in the end leads us to the invention of the essence of religion. The call is getting more actual and urgent, particularly during the pandemic of Covid-19. There is a distance between the ideals of religion and the reality of religious life. Religion, which is supposed to be a place to find safety, peace, and solidarity turns to be counter productive. The above phenomena may be a signal that the effort to the wise appreciation of religion must always be cultivated. The ability to understand the content of a "sacred text" should be maintained and discussed along with the context, culture, and era, so we can show the elegant, humane, and civilized face of religion. Covid-19 becomes a challenge as well as correction for the adherents. Even, the relevance of religion is on concern within human life. This study has limitations because it only analyzes secondary data from the media. Read and interpret the phenomena that arise without direct interviews to reveal the motivations of the perpetrators. It is therefore imperative that future field research be carried out to complement this study. Finally, the problem of religiosity during Covid-19 may become a reflection of the history in the future. Religion and science ideally reinforce one another, not mutually negating.

\section{References}

[1] R. A. Tejomukti, “Tanpa Izin, Jamaah Tabligh Tetap Gelar Ijtima’ Dunia di Gowa,” Republika, 2020. [Online]. Available: https://republika.co.id/berita/q7e4lx327/tanpa-izin-jamaah- 
tablightetap-gelar-ijtima-dunia-di-gowa. [Accessed: 27-Jul-2020].

[2] E. Ipelona, "Diminta Ditunda Karena Virus Corona, Misa di Ruteng Tetap Berlangsung," Kompas TV, 2020. [Online]. Available: https://www.kompas.tv/article/72090/diminta-ditundakarena-virus-corona-misa-di-ruteng-tetap-berlangsung. [Accessed: 27-Jul-2020].

[3] W. J. Wildman, J. Bulbulia, R. Sosis, and U. Schjoedt, "Religion and the COVID-19 pandemic," Relig. Brain Behav., vol. 10, no. 2, pp. 115-117, 2020.

[4] J. Griffith, "Pastor defies coronavirus order, draws over $1 \mathrm{~K}$ people to services," NBC NEWS, 2020. [Online]. Available: https://www.msn.com/en-us/news/us/pastor-defies-coronavirusorder-draws-over-1k-people-to-services/ar-

BB11HwQ3?fbclid=IwAR1 SuGp5PLupVrEDxieOr3ZQveeZah5ZYOGAXm7N45QE5dD4JoX Z6kfjr3s. [Accessed: 12-Aug-2020].

[5] B. Bostock, "South Korea is testing 200,000 members of a doomsday church linked to more than $60 \%$ of its coronavirus cases," Business Insider, 2020. [Online]. Available: https://www.businessinsider.com/south-korea-tests-every-shincheonji-cult-membercoronavirus-outbreak-2020-2?r=US\&IR=T. [Accessed: 12-Aug-2020].

[6] R. Rashid, "Being Called a Cult Is One Thing, Being Blamed for an Epidemic Is Quite Another," The New Work Time, 2020. .

[7] C. E. Lorea, "Religious returns, ritual changes and divinations on COVID-19," Soc. Anthropol., vol. 1, no. April, pp. 1-2, 2020.

[8] K. Brewer-Smyth and H. G. Koenig, "Could spirituality and religion promote stress resilience in survivors of childhood trauma?," Issues Ment. Health Nurs., vol. 35, no. 4, pp. 251-256, 2014.

[9] F. K. Hashmi, Q. Iqbal, N. Haque, and F. Saleem, "Religious Cliché and Stigma: A Brief Response to Overlooked Barriers in COVID-19 Management.," J. Relig. Health, no. 0123456789, pp. 1-4, 2020.

[10] M. A. Abdullah, "Mendialogkan nalar agama dan sains modern di tengah pandemi covid-19*," Maarif Inst., vol. 15, no. 1, pp. 11-39, 2020.

[11] M. Maliki, "Covid-19, Agama, dan Sains,” Maarif Inst., vol. 15, no. 1, 2020.

[12] M. Alkaf, “Agama, Sains, Dan Covid-19: Perspektif Sosial-Agama,” Maarif Inst., vol. 15, no. 1, 2020 .

[13] W. O. Z. Z. Toresano, "Integrasi Sains dan Agama: Meruntuhkan Arogansi di Masa Pandemi Covid-19," Maarif Inst., vol. 15, no. 1, 2020.

[14] S. Hjarvard, H. Christensen, and M. Moberg, Mediatization and Religion . Nordic Perspectives Nordic Perspectives, no. July. 2012.

[15] E. Gross, "Phenomenology and hermeneutics in brazilian religious studies," Open Theol., vol. 4 , no. 1, pp. 246-257, 2018.

[16] S. Zaluchu and F. Widjaja, "A Phenomenology Approach: Religious Significance of Mandala in Ancient Nias Culture," no. January, 2019.

[17] Z. M. Kostićová, "Axis Mundi in the Tropics : Uses and Abuses of Eliade' s Phenomenology of Religion in the Schelean Maya Studies," vol. 19, no. 2, pp. 57-80, 2019.

[18] H. S. Ahimsa-putra, "FENOMENOLOGI AGAMA : Pendekatan Fenomenologi untuk," Walisongo, vol. 20, no. November 2012, pp. 271-304, 2012.

[19] LUDGER HAGEDORN \& MICHAEL STAUDIGL, “ON SECULARISM AND ITS DISCONTENTS: CHARTING PATHWAYS WITH A PHENOMENOLOGY OF 
RELIGION,"JCRT, vol. 17, no. 2, pp. 238-253, 2018.

[20] N. A. Ridlwan, "Pendekatan Fenomenologi Dalam Kajian Agama," KOMUNIKA J. Dakwah dan Komun., vol. 7, no. 2, 1970.

[21] P. Mckenzie, "Phenomenology of Religion : A Systematic Approach," vol. 37, no. 3, pp. 5-19, 2009.

[22] P. Pandor, "Fenomenologi agama menuju penghayatan agama yang dewasa," Filsafat, pp. 10 28.

[23] M. Momen, "Book Review - The Phenomenon of Religion The Phenomenon of Religion: A Thematic Approach," Oneworld Publ. Oxford, pp. 219-226, 1999.

[24] Thomas Ryba, "Phenomenology of Religion,” J. Relig. Health, vol. 3, no. 2, pp. 253-287, 2009.

[25] A. U. Adamu, "Epistemological Dichotomy and Scriptural Transferability: Towards a New Paradigm for Muslim Hausa Indigenous Knowledge," Bayero Univ. Niger.

[26] G. K. Aguilar, H. A. Campbell, M. Stanley, and E. Taylor, "Communicating mixed messages about religion through internet memes," Inf. Commun. Soc., vol. 20, no. 10, pp. 1498-1520, 2017.

[27] H. Campbell, "Internet and Religion,” Handb. Internet Stud., no. April 2011, pp. 232-250, 2011.

[28] I. Abdullah, "DI BAWAH BAYANG-BAYANG MEDIA:Kodifikasi, Divergensi, dan Kooptasi Agama di Era Internet I,” Sabda, vol. 12, no. 2, pp. 51-66, 2017.

[29] S. Hjarvard, "The mediatisation of religion: Theorising religion, media and social change," Cult. Relig., vol. 12, no. 2, pp. 119-135, 2011.

[30] Kyle Mantyla, "Perry Stone Claims America's Coronavirus Outbreak Is A 'Reckoning' For Allowing Abortion And Gay Marriage," 2020. [Online]. Available: https://www.richarddawkins.net/2020/03/perry-stone-claims-americas-coronavirus-outbreak-isa-reckoning-for-allowing-abortion-and-gay-marriage/. [Accessed: 13-Aug-2020].

[31] B. Browning, "Defiant pastor who kept church open despite coronavirus warnings dies a week later from COVID-19," 2020. [Online]. Available:

https://www.lgbtqnation.com/2020/04/defiant-pastor-kept-church-open-despite-coronaviruswarnings-dies-week-later-covid-19/. [Accessed: 15-Aug-2020].

[32] A. Bollinger, "Pastor who laid hands on Trump says avoiding coronavirus is for "pansies,", LGBTQNATION, 2020. [Online]. Available: https://www.lgbtqnation.com/2020/03/pastor-laidhands-trump-says-avoiding-coronavirus-pansies/. [Accessed: 15-Aug-2020].

[33] DWNew, "Hindu group hosts cow urine drinking party to ward off coronavirus," DW News, 2020. [Online]. Available: https://www.dw.com/en/hindu-group-hosts-cow-urine-drinkingparty-to-ward-off-coronavirus/a-52773262. [Accessed: 15-Aug-2020].

[34] D. Siddiqui, "Hindu group offers cow urine in a bid to ward off coronavirus," Reuters, 2020. [Online]. Available: https://www.reuters.com/article/us-health-coronavirus-india-cow-urine$\mathrm{pa} /$ hindu-group-offers-cow-urine-in-a-bid-to-ward-off-coronavirus-idUSKBN2110D5. [Accessed: 15-Aug-2020].

[35] J. Irish, "Coronavirus: Hindu group hosts 'cow urine drinking party' to cure illness despite lack of evidence.," INDEPENDENT, 2020. [Online]. Available: https://www.independent.co.uk/news/world/asia/coronavirus-news-hindu-cow-urine-drinkingparty-india-a9402491.html. [Accessed: 13-Aug-2020].

[36] S. Ghosh, "Ghosh, S. Can cow urine cure Coronavirus? Four of the most ridiculous myths about 
COVID-19 busted.," EdexLive, 2020. [Online]. Available:

https://www.edexlive.com/news/2020/mar/18/can-cow-urine-cure-coronavirus-four-of-themost-ridiculous-myths-about-covid-19-busted-10747.html. [Accessed: 13-Aug-2020].

[37] Riham Darwish, "Sacred soil, cow urine and other rituals: People turn to religion to deal with the corona virus," 2020. [Online]. Available: https:/www.albawaba.com/node/sacred-soil-cowurine-and-other-rituals-people-turn-religion-deal-coronavirus-1345263. [Accessed: 13-Aug2020].

[38] S. N. Park, "Cults and Conservatives Spread Coronavirus in South Korea," 2020. [Online]. Available: https://foreignpolicy.com/2020/02/27/coronavirus-south-korea-cults-conservativeschina/. [Accessed: 13-Aug-2020].

[39] Statista, "COVID-19 cases related to Shincheonji Church South Korea 2020," Statista Research Department, 2020. .

[40] S. Dein, K. Loewenthal, C. A. Lewis, and K. I. Pargament, "COVID-19, mental health and religion: an agenda for future research," Ment. Heal. Relig. Cult., vol. 23, no. 1, pp. 1-9, 2020.

[41] N. Daim, "Tabligh gathering cluster contributes highest positive Covid-19 figures," New Straits Times, 2020. [Online]. Available:

https://www.nst.com.my/news/nation/2020/04/581317/tabligh-gathering-cluster-contributeshighest-positive-covid-19-figures. [Accessed: 13-Aug-2020].

[42] M. A.-H. and I. T. M. Zia ur-Rehman, “'God Will Protect Us': Coronavirus Spreads Through an Already Struggling Pakistan,” The New York Times, 2020. [Online]. Available: https://www.nytimes.com/2020/03/26/world/asia/pakistan-coronavirus-tablighi-jamaat.html. [Accessed: 13-Aug-2020].

[43] P. Kumar, "30 Per Cent Of Coronavirus Cases Linked To Delhi Mosque Event: Government," 2020. [Online]. Available: https://www.ndtv.com/india-news/coronavirus-tablighi-jamaat-30per-cent-of-coronavirus-cases-linked-to-delhi-mosque-event-government-2206163. [Accessed: 13-Aug-2020].

[44] N. Tarnopolsky, "Ultra-Orthodox Jews hit disproportionately hard by Israel's coronavirus outbreak," Los Angeles Times, 2020. [Online]. Available: https://www.latimes.com/worldnation/story/2020-04-07/ultra-orthodox-jews-hit-disproportionately-hard-in-israels-coronavirusoutbreak. [Accessed: 13-Aug-2020].

[45] Moska Najib, "At least 40,000 quarantined in India after single priest spread coronavirus," 2020. [Online]. Available: https://www.nbcnews.com/news/world/least- 40-000-quarantinedindia-after-single-priest-spread-coronavirus-n1171261. [Accessed: 13-Aug-2020].

[46] D. M. Halbfinger, "Virus Soars Among Ultra-Orthodox Jews as Many Flout Israel's Rules," The New York Times, 2020. .

[47] H. Beech, "None of Us Have a Fear of Corona': The Faithful at an Outbreak's Center," The New York Times, 2020. [Online]. Available: https://www.nytimes.com/2020/03/20/world/asia/coronavirus-malaysia-muslims-outbreak.html. [Accessed: 13-Aug-2020].

[48] Muhammad Ilman Nafi'an, “Ustaz Somad Beri Penjelasan soal Anggapan 'Virus Corona Tentara Allah,"” detikNews, 2020. [Online]. Available: https://news.detik.com/berita/d4920843/ustaz-somad-beri-penjelasan-soal-anggapan-virus-corona-tentara-allah. [Accessed: 14Aug-2020].

[49] M. S. Albanna, "MUI Bela Ustaz Abdul Somad soal Corona Tentara Allah," TAGAR id, 2020. [Online]. Available: https://www.tagar.id/mui-bela-ustaz-abdul-somad-soal-corona-tentaraallah. [Accessed: 14-Aug-2020]. 
[50] J. E. Lato, “Coronavirus: God's Army and Pork Consumption in Indonesia," Gatestone Institute International, 2020. [Online]. Available: https://www.gatestoneinstitute.org/15822/coronavirusindonesia. [Accessed: 14-Aug-2020].

[51] M. Alvin Nur Choironi, "Quraish Shihab: Saya Tidak Setuju Pendapat Corona Tentara Allah,” 2020. [Online]. Available: https://islami.co/quraish-shihab-tidak-setuju-pendapat-coronatentara-allah/. [Accessed: 14-Aug-2020].

[52] Z. F. Johan, "Virus dan Obat Penangkalnya dalam Perspektif Masyarakat Aceh," Serambinews, 2020. [Online]. Available: https://aceh.tribunnews.com/2020/03/23/virus-dan-obatpenangkalnya-dalam-perspektif-masyarakat-aceh. [Accessed: 16-Aug-2020].

[53] Serambinews, "Memerahkan Jari Dengan Daun Inai Dipercaya Bisa Cegah Corona, Benarkah?," Serambinews, 2020. [Online]. Available:

https://aceh.tribunnews.com/2020/04/02/memerahkan-jari-dengan-daun-inai-dipercaya-bisacegah-corona-benarkah. [Accessed: 16-Aug-2020].

[54] Serambinews, "MPU Aceh Bolehkan Warga Shalat Tarawih di Masjid Asal Terpenuhi Syarat Ini," Serambinews, 2020. [Online]. Available: https://aceh.tribunnews.com/2020/04/21/mpuaceh-bolehkan-warga-shalat-tarawih-di-masjid-asal-terpenuhi-syarat-ini. [Accessed: 16-Aug2020].

[55] MUI, "MUI Keluarkan Tausiyah Ramadhan 1441 H di Tengah Wabah Covid-19," 2020. [Online]. Available: https://mui.or.id/berita/27848/mui-keluarkan-tausiyah-ramadhan-1441-hdi-tengah-wabah-covid-19/. [Accessed: 16-Aug-2020].

[56] Kontri, "Menag: Masih Pandemi, Salat Id di Rumah dengan Keluarga Inti,” Kemenag, 2020. [Online]. Available: https://kemenag.go.id/berita/read/513332/menag-- masih-pandemi--salatid-di-rumah-dengan-keluarga-inti. [Accessed: 16-Aug-2020].

[57] Kontri, "Dirjen Bimas Islam, Ramadan di Rumah Tak Mengurangi Kualitas Ibadah," Kemenag, 2020. [Online]. Available: https://kemenag.go.id/berita/read/513202/dirjen-bimas-islam-ramadan-di-rumah-tak-mengurangi- kualitas-ibadah. [Accessed: 16-Aug-2020].

[58] B. NEWS, “Coronavirus: South Korea church leader apologises for virus spread," 2020. [Online]. Available: https://www.bbc.com/news/world-asia-51701039. [Accessed: 15-Aug2020].

[59] A. B. D. C. Tom Allard, "Muslim event in Indonesia stopped amid coronavirus fears," REUTERS, 2020.

[60] M. Kencana and Wirawan, "Media Asing Sorot Jemaah Tabligh Indonesia: Kami Lebih Takut pada Tuhan," Kompas.com, 2020. [Online]. Available: https:/www.kompas.com/global/read/2020/03/19/073816170/media-asing-sorot-jemaahtabligh-indonesia-kami-lebih-takut-pada-tuhan?page=all. [Accessed: 15-Aug-2020].

[61] R. Belarminus, "Ini Alasan Misa Penahbisan Uskup Ruteng Tak Bisa Ditunda," Kompas.com, 2020. [Online]. Available: https://regional.kompas.com/read/2020/03/19/12213691/ini-alasanmisa-penahbisan-uskup-ruteng-tak-bisa-ditunda. [Accessed: 15-Aug-2020].

[62] BBCNEWS, "Coronavirus: Bangladesh mass prayer event prompts alarm," BBCNEWS, 2020. [Online]. Available: https://www.bbc.com/news/world-asia-51956510. [Accessed: 15-Aug2020].

[63] AFP, "Massive Bangladesh coronavirus prayer gathering sparks outcry," Bangkok Post, 2020. [Online]. Available: https://www.bangkokpost.com/world/1882015/massive-bangladeshcoronavirus-prayer-gathering-sparksoutcry. [Accessed: 15-Aug-2020].

[64] K. Heren, "Muslims should delay making Hajj plans due to coronavirus fears, says Saudi 
Arabia," EveningStandard, 2020. [Online]. Available:

https://www.standard.co.uk/news/world/saudi-arabia-muslims-hajj-coronavirus-a4403636.html. [Accessed: 15-Aug-2020].

[65] I. Syahputra, “Ada Qadariyah Dan Jabariyah dalam Virus Corona,” REPUBLIKA, 2020. [Online]. Available: https://republika.co.id/berita/q7f80o385/ada-qadariyah-dan-jabariyahdalam-virus-corona. [Accessed: 19-Aug-2020].

[66] A. S. Notonegoro, "Sains Melampaui Politik dan Agama," Maarif Inst., vol. 15, no. 1, 2020.

[67] A. N. Farzan, "Because coronavirus has led to enough sacrifices, Catholic bishops say it's okay to eat meat on Fridays during Lent," The Washington Post, 2020. .

[68] A. H.-S. Crystal L. Park, Donald Edmondson, "Why Religion? Meaning as Motivation," University of Oklahoma ILL, 2013, pp. 157-171.

[69] F. Thompkins, P. Goldblum, T. Lai, T. Hansell, A. Barclay, and L. M. Brown, "A Culturally Specific Mental Health and Spirituality Approach for African Americans Facing the COVID-19 Pandemic," Psychol. Trauma Theory, Res. Pract. Policy, vol. 12, no. 5, pp. 455-456, 2020. 